\title{
Molecular Analysis of Lipoxygenases Associated with Nodule Development in Soybean
}

\author{
Satomi Hayashi, Peter M. Gresshoff, and Mark Kinkema \\ Australian Research Council Centre of Excellence for Integrative Legume Research, The University of Queensland, \\ St. Lucia, QLD 4072, Australia; The University of Queensland, St. Lucia, Brisbane, QLD 4072, Australia
}

Submitted 26 October 2007. Accepted 14 February 2008.

\begin{abstract}
We utilized transcriptional profiling to identify genes associated with nodule development in soybean. Many of the candidate genes were predicted to be involved in processes such as defense, metabolism, transcriptional regulation, oxidation, or iron storage. Here, we describe the detailed characterization of one specific class of genes that encode the enzyme lipoxygenase (LOX). The LOX9 and LOX10 genes identified by microarray analysis represent novel soybean LOXs expressed in developing nodules. LOX expression during nodulation was relatively complex, with at least eight different LOX genes expressed in soybean nodules. Histochemical analyses utilizing $L O X 9$ promoter: $\beta$ glucuronidase (GUS) fusion constructs in transgenic soybean hairy roots suggest that this gene is involved in the growth and development of specific cells within the root and nodules. In soybean roots, $L O X 9$ was expressed specifically in the developing phloem. In nodules, the expression of $L O X 9$ was correlated with the development of cells in the vasculature and lenticels. The use of RNAi in transgenic hairy roots reduced LOX expression by approximately 95\%. Despite this significant reduction in LOX expression, there was no detectable effect on the development of roots or nodules. Our findings are discussed with respect to the potential function of LOXs in nodulation.
\end{abstract}

Additional keywords: AON, Glycine max.

Legumes have the ability to form nitrogen-fixing root nodules when grown under conditions where this essential nutrient is limiting. Nodule formation involves a symbiotic association with soil-living bacteria collectively called rhizobia. This symbiotic relationship between legume roots and rhizobia allows the plants to use atmospheric $\mathrm{N}_{2}$ as a source of nitrogen for their growth and development. This process is important for plant growth but also plays a key role in providing nitrogen to ecological and agricultural systems (Graham and Vance 2003).

Understanding the processes involved in nodulation will provide insight on both plant organ development and plantmicrobe interactions (Kinkema et al. 2006). Nodulation is a highly host-specific process in which particular rhizobial

Corresponding author: P. M. Gresshoff; Telephone: +61 73365 3550; Fax +61 73365 3556; E-mail: p.gresshoff@uq.edu.au

Sequence data for $L O X 9, L O X 10$, and the $L O X 9$ promoter are available from the GenBank database under accession numbers EU003576, EU003577, and EU009396, respectively.

* The $\boldsymbol{e}$-Xtra logo stands for "electronic extra" and indicates that three supplemental figures and one supplemental table are published online. strains are able to infect only a limited range of plant species (Stacey et al. 2006). This process is initiated when the rhizobia sense flavonoid molecules that are secreted by the plant root. Flavonoids induce expression of the bacterial nodulation $(\mathrm{Nod})$ genes which code for proteins that are involved in the synthesis and secretion of lipo-chito-oligosacharides (Nod factors) (Spaink 2000). Nod factors are essential molecules for rhizobia infection, and their perception by the host plant triggers the activation of a variety of early symbiotic responses in the root which lead to the formation of nodules (Kinkema et al. 2006; Stacey et al. 2006). In the root epidermal cells, Nod factor perception by LysM-type receptor kinases (Limpens et al. 2003; Madsen et al. 2003; Radutoiu et al. 2003) leads to signaling cascades which induce a series of biochemical responses and the expression of a number of genes known to act in early stages of nodulation. Morphological changes of root hairs and cell division in the root cortex and pericycle also are induced by the Nod factors (Esseling et al. 2003; Journet et al. 1994; Kinkema et al. 2006). A number of signaling components involved in nodulation have been identified by the study of mutants defective in nodule formation (Stacey et al. 2006). Additional plant proteins, such as leghemoglobin (Ott et al. 2005) and sulfate transporters (Krusell et al. 2005) also have been characterized and found to be essential for the establishment of the mature, functional nodule.

Despite the benefit of nitrogen fixation, nodulation is an energetically expensive process for the legume seedling. Autoregulation of nodulation (AON) is a long-distance signaling network which acts to limit the proliferation of nodules (Caetano-Anollés and Gresshoff 1991; Calvert et al. 1984; Delves et al. 1986; Kosslak and Bohlool 1984). Plants defective in AON (i.e., nts mutants) show a super (hyper)-nodulating phenotype (Carroll et al. 1985a and b; Krusell et al. 2002; Oka-Kira et al. 2005; Searle et al. 2003). A putative transmembrane leucine-rich-repeat (LRR) receptor kinase is one of the key regulators in the AON pathway (Krusell et al. 2002; Nishimura et al. 2002; Schnabel et al. 2005; Searle et al. 2003). In soybean, this receptor kinase is referred to as GmNARK (Glycine max nodulation autoregulation receptor kinase) (Krusell et al. 2002; Searle et al. 2003). It is thought that $\mathrm{AON}$ is initiated by a root-derived, rhizobia-induced signal (Q) that functions to activate (directly or indirectly) the LRR receptor kinase in the shoot. Receptor activation, which likely occurs in the phloem (Nontachaiyapoom et al. 2007), then initiates the production of a shoot-derived inhibitor (SDI) that is sent to the root to negatively regulate nodule numbers. At present, very little is known about the mechanism by which the LRR receptor kinase mediates the long-distance signaling in $\mathrm{AON}$, and the nature of the root and shoot signals is not known.

The characterization of additional genes whose expression is associated with nodulation and AON will help to expand our 
understanding of these signaling pathways. Transcriptional profiling in Medicago truncatula and Lotus japonicus has identified hundreds of genes whose expression is either up- or downregulated at different stages of nodule development (Colebatch et al. 2002; Lohar et al. 2006). In this article, we describe the use of Affymetrix GeneChip microarrays to identify genes that are associated with nodule development in soybean. One class of identified genes encodes the enzyme lipoxygenase (LOX).

LOXs (EC1.13.11.12) are nonheme iron-containing dioxygenases that are widely distributed among eukaryotes (Brash 1999). This enzyme catalyses the addition of molecular oxygen at either the C- 9 or C-13 residue of polyunsaturated fatty acids containing a cis, cis-1,4-pentadiene structure to produce an unsaturated fatty acid hydroperoxide (Grechkin 1998; Mohammadi and Karr 2003; Porta and Rocha-Sosa 2002; Veronico et al. 2006). In plants, linoleic (C18:2) and linolenic (C18:3) acids, which are the most abundant fatty acids in the lipid fraction of the plant membranes (Veronico et al. 2006), are the primary substrates for LOXs (Siedow 1991; Veronico et al. 2006). Products of the LOX pathway are groups of acyclic or cyclic compounds collectively called oxylipins (Porta and Rocha-Sosa 2002). Several oxylipin molecules such as jasmonic acid (JA) (Sembdner and Parthier 1993), traumatin (Zimmerman and Coudron 1979) and $\beta$-ionone (Hildebrand et al. 1991; IslasFlores et al. 2002; Loiseau et al. 2001) are known to act as growth regulators and signaling molecules. LOXs are multifunctional enzymes that are known to be involved in plant growth and development (Siedow 1991), senescence (Fobel et al. 1987), wounding (Hildebrand 1989), lipid mobilization during germination (Feussner et al. 1995), and defense against pests and diseases (Croft et al. 1993). Some LOXs also are used as storage proteins in vegetative tissue during growth (Dubbs and Grimes 2000; Fischer et al. 1999; Tranbarger et al. 1991).

In addition, the identification of LOX proteins and transcripts in nodules has been reported in a number of leguminous plant species (Mohammadi and Karr 2003; Perlick et al. 1996; Porta and Rocha-Sosa 2000; Porta et al. 1999; Szczyglowski et al. 1997; Wisniewski et al. 1999). These studies have led to speculation about the potential roles for LOXs in legume-rhizobia symbiosis and nodule development (Gardner et al. 1996; Perlick et al. 1996; Porta et al. 1999). However, no studies have yet been conducted to analyze the potential function of LOXs in nodulation or to determine whether LOXs are indeed required for nodule development. In addition, no soybean LOXs with a proposed function in nodulation have been characterized to date.

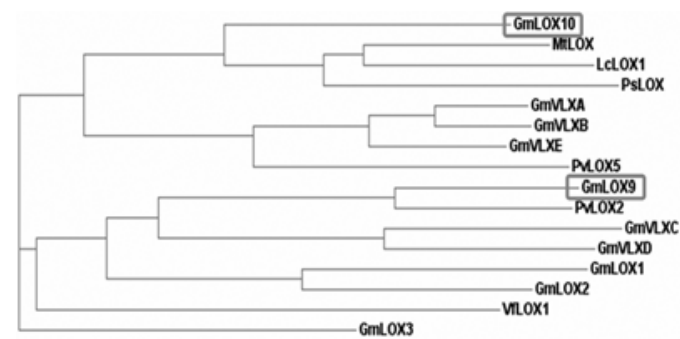

Fig. 1. Phylogenetic tree of selected legume lipoxygenases (LOXs). This tree showing the relatedness of LOXs was generated by aligning the fulllength protein sequences (using ClustalW) from soybean LOX9 (GmLOX9), soybean LOX10 (GmLOX10), LOXs which appeared to be highly similar to soybean LOX9/10, seven other soybean LOXs, and nodule LOXs from Vicia faba and Phaseolus vulgaris. Gm = Glycine max, Lc = Lens culinaris, $\mathrm{Mt}=$ Medicago truncatula, $\mathrm{Ps}=$ Pisum sativum, $\mathrm{Pv}=$ Phase olus vulgaris and $\mathrm{Vf}=V$. faba. GenBank accession numbers for those proteins not described above are as follows: LcLOX1 = P38414; PsLOX = CAA53730; and GmVLXA, GmVLXB, GmVLXC, GmVLXD, and GmVLXE = P38417, AAB67732, AAA96817, CAA39604, and AAC49159, respectively.
Here, we describe a detailed investigation of soybean LOXs associated with nodule development. Our results provide new insights into the complexity and potential roles of the LOX gene family in legume nodulation.

\section{RESULTS}

\section{Transcriptional profiling of soybean roots.}

To identify genes that may play a role in nodule development, we analyzed the expression of approximately 37,500 soybean (G. max) transcripts using the Affymetrix GeneChip soybean genome arrays. Root sections isolated from inoculated wild-type and nts1007 supernodulating mutant seedlings were compared with the same root regions of the uninoculated wild type. The selected root zone represents the "susceptible" region of wildtype roots where a large proportion of developing nodules are formed (Bhuvaneswari et al. 1980). Our analyses were conducted at a relatively early stage of nodulation (5 days posttreatment $[\mathrm{dpt}])$, at which time no nodules were visible on the root surface. At this time point, 48 genes were identified that were predicted to be differentially expressed at least twofold in inoculated roots (of both the wild type and $n t s 1007$ ) relative to uninoculated roots (Supplemental Table 1). The expression of a majority of these genes $(n=41)$ was predicted to increase in response to inoculation, suggesting that many of the changes occurring at this stage involve gene activation rather than suppression. The differential expression of most of the candidate genes was found to be greater in $n t s 1007$, which is likely due to the increased number of nodule foci that are developing on these supernodulating roots (Mathews et al. 1989). Many of the genes can be classified as functioning in defense, metabolism, transcriptional regulation, oxidation, or iron storage. One class of genes that increased in response to nodulation was $L O X$.

\section{Sequence analysis of two novel soybean $L O X s$.}

To further analyze the two candidate $L O X$ genes of interest and their relationship with nodulation, we cloned and sequenced the full-length cDNAs. We amplified the unknown 5' sequences of $L O X 9$ and $L O X 10$ from the known $3^{\prime}$ end sequences using $5^{\prime}$ rapid amplification of cDNA ends (RACE). Sequencing analysis of the full-length cDNAs identified an open reading frame of 2,598 bp in length (865 amino acids) for LOX9 and 2,601 bp (866 amino acids) for LOX10.

Database searches with the nucleotide sequence and the predicted protein sequence found that LOX9 was most similar to PvLOX2 (GenBank accession number AAB18970) of Phaseolus vulgaris (common bean). Previous work demonstrated that $P v L O X 2$ was highly expressed in nodules (Porta et al. 1999). The sequence alignment between these two proteins showed $88 \%$ identity and $95 \%$ similarity, suggesting that $L O X 9$ may be the soybean ortholog of $P v L O X 2$. The predicted protein for $L O X 10$ was most similar to a LOX from $M$. truncatula (GenBank accession number ABE88354), displaying $82 \%$ identity and $89 \%$ similarity. LOX9 and LOX10 were only $67 \%$ identical ( $79 \%$ similarity), which is significantly lower than that described above. This suggests that these two LOXs may have functionally diverged. In addition, neither LOX9 nor LOX10 showed high similarity ( $<75 \%$ identity) to the previously identified soybean LOXs (Fig. 1). Moreover, neither of the two LOXs showed a high degree of similarity to the broad bean VfLOX1 (Perlick et al. 1996) or common bean PvLOX5 (Porta and Rocha-Sosa 2000), which previously were shown to be expressed in nodules.

Analysis of the predicted proteins for LOX9 and LOX10 identified a polycystin-1, LOX, $\alpha$-toxin (PLAT), or LOX homology (LH2) domain (Supplemental Fig. 1), which is found among various proteins that are associated with membranes or 
lipids (Bateman and Sandford 1999). A LOX conserved motif, which consists of 38 amino acids that includes five conserved histidines (His) and a sixth His approximately 160 amino acids downstream (Steczko et al. 1992), also was identified in LOX9 and LOX10. The His residues in this motif are important for the enzyme activity, and the second, third, and sixth His residues are critical for iron binding (Steczko et al. 1992). Another two conserved amino acids, Asn-721 and Ile-865 (LOX9)/-866 (LOX10) that also act as iron-ligands (Boyington et al. 1990; Chen et al. 1994; Shibata and Axelrod 1995) were identified. Some LOXs are predicted to be localized to plastids (Bell and Mullet 1993; Peng et al. 1994). However, neither LOX9 nor LOX10 was predicted to contain a signal or transit peptide (data not shown), suggesting that they likely are localized to the cytosol.

In plants, LOXs are classified into 9- or 13-LOX according to their positional specificity of the substrate (linoleic or linolenic acid) oxygenation (Gardner 1991). Space-filling residues such as His or Phe at the substrate-binding pocket are characteristic of 13-LOXs, whereas small amino acids such as Val characterize 9-LOX (Hornung et al. 1999; Liavonchanka and Feussner 2006). Protein sequence comparisons of the two LOXs to some of the other characterized LOXs indicated that the amino acids determining their regio-specificity are Ser-583 and Phe-584 for LOX9 and Thr-583 and Phe-584 for LOX10, indicating that these two LOXs are likely 13-LOXs. Phylogenetic analysis (Feussner and Wasternack 2002) provides additional evidence that LOX9 and LOX10 are most similar to 13LOXs (Supplemental Fig. 2).

\section{$L O X$ expression in roots and nodules.}

To study the change in RNA expression of LOX9 and LOX1O in relation to Bradyrhizobium spp. inoculation and nodule development, time-course expression studies were conducted on roots and nodules. $L O X 9$ and $L O X 10$ were expressed in the roots of inoculated and uninoculated wild-type and $n t s$ plants. In whole roots, there were no major changes in expression of LOX9 or LOX10 throughout the period in which the expression of these genes was studied (Fig. 2). The average expression of LOX9, however, increased approximately threefold in the inoculated $n t s$ roots at $7 \mathrm{dpt}$ (Fig. 2), which likely is due to high expression of this gene in developing nodules (discussed below).

In isolated root nodules at various stages of development, the expression of $L O X 9$ increased dramatically with nodule age while LOX10 expression decreased slightly (Fig. 3). LOX9 expression in nodules was significantly higher than that of $L O X 10$, showing up to 330-fold higher expression during nodule development.

The transcriptional profiling analyses used to identify $L O X 9$ and $L O X 10$ were conducted on root tissue at a single time point $(5 \mathrm{dpt})$ and may not have identified all soybean $L O X \mathrm{~s}$ that are expressed in developing nodules. To investigate the complexity of $L O X$ expression during nodulation, we analyzed the expression of most of the additional known soybean $L O X \mathrm{~s}$ by using quantitative real-time polymerase chain reaction (qRT-PCR) of nodule RNA. The vegetative LOXs, $v l x A$ to $-E$, were highly expressed in nodules (Fig. 3). Expression of another LOX, LOX11, was also relatively abundant in nodules (Fig. 3). The seed LOX2 gene appeared to be weakly expressed in nodules; however, this expression was barely detectable and was significantly lower than that of the other LOXs (Fig. 3). These results reveal that developing soybean nodules abundantly express a wide variety of LOXs.

\section{Expression of $L O X 9$ and $L O X 10$ in different tissues.}

To obtain additional information on the expression of $L O X 9$ and $L O X 10$ in soybean, we compared their expression among different tissues of the plant. Expression of LOX9 was significantly higher than LOX10 expression in all tissues examined except for root, where the expression of these genes was relatively similar (Fig. 4). Expression of $L O X 9$ was highest in mature nodules (21 days postinoculation [dpi]), with expression being more than 60 times higher than that observed for the whole root (Fig. 4). Expression of both $L O X \mathrm{~s}$, especially $L O X 9$, was significantly higher in the root tip compared with expression in the whole root system (Fig. 4). This finding suggests that the expression of these $L O X$ s may be associated with actively growing tissues.

\section{LOX9 promoter:: $\beta$-glucuronidase expression analysis} in transgenic hairy roots.

A database search using the $L O X 9 \mathrm{cDNA}$ sequence led to the identification of a soybean BAC clone, 23M24 (GenBank accession number ED687910), which contained the LOX9 gene. Approximately $2 \mathrm{~kb}$ of sequence $5^{\prime}$ to the $L O X 9$ translation start

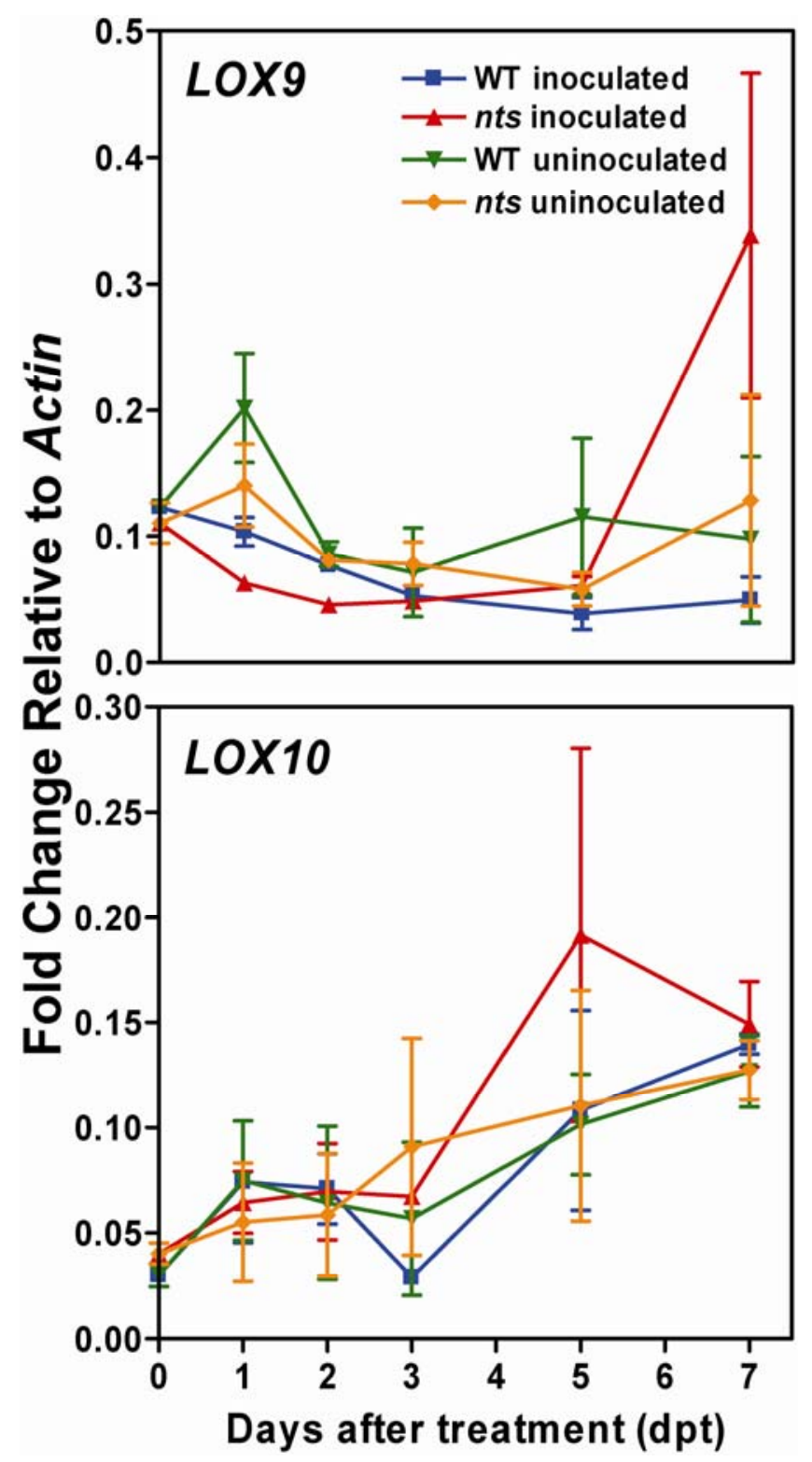

Fig. 2. Time-course expression analysis of lipoxygenase 9 (LOX9) and 10 (LOX10) in soybean root. Expression of LOX9 and LOX10 was analyzed by quantitative real-time polymerase chain reaction of RNA isolated from whole roots of inoculated and uninoculated wild-type and supernodulating mutant (nts1007 and nts382) plants at 0, 1, 2, 3, 5, and 7 days post-treatment (dpt). Error bars indicate the standard deviation of the data resulting from two independent experiments. 
site (TSS) was obtained by sequencing this clone (Supplemental Fig. 3). Sequence from 5' RACE products showed that the transcription start site was located 84 nucleotides upstream of the TSS. Furthermore, database analysis identified 59 different motifs which may appear multiple times within the 1,969-bp LOX9 potential promoter region. This includes the putative TATA box at $117 \mathrm{bp}$ upstream of the TSS and the respective CAAT box at -208 bp.

To analyze the expression of LOX9 at the cellular level in roots and nodules, transgenic hairy roots that expressed $\beta$-glucuronidase (GUS) under the control of the putative LOX9 promoter region were generated. We utilized two different promoter sequences consisting of either 773 or 1,966 bp of sequence $5^{\prime}$ of the LOX9 TSS. Both promoter sequences gave identical patterns of GUS activity (data not shown), indicating that all the regulatory elements necessary for $L O X 9$ expression in roots likely are present in the 773-bp 5' region.

GUS staining became evident in the root tips within $30 \mathrm{~min}$. After $2 \mathrm{~h}$ of staining, GUS activity was evident in the root tips, root vasculature, and developing lenticels of older nodules (Fig. 5A and I). Overnight incubation revealed GUS staining of the nodule primordia and young nodules (Fig. 5D through $\mathrm{H}$ ). In the root vasculature, GUS activity was strongest in the younger vascular bundles and disappeared in the more mature

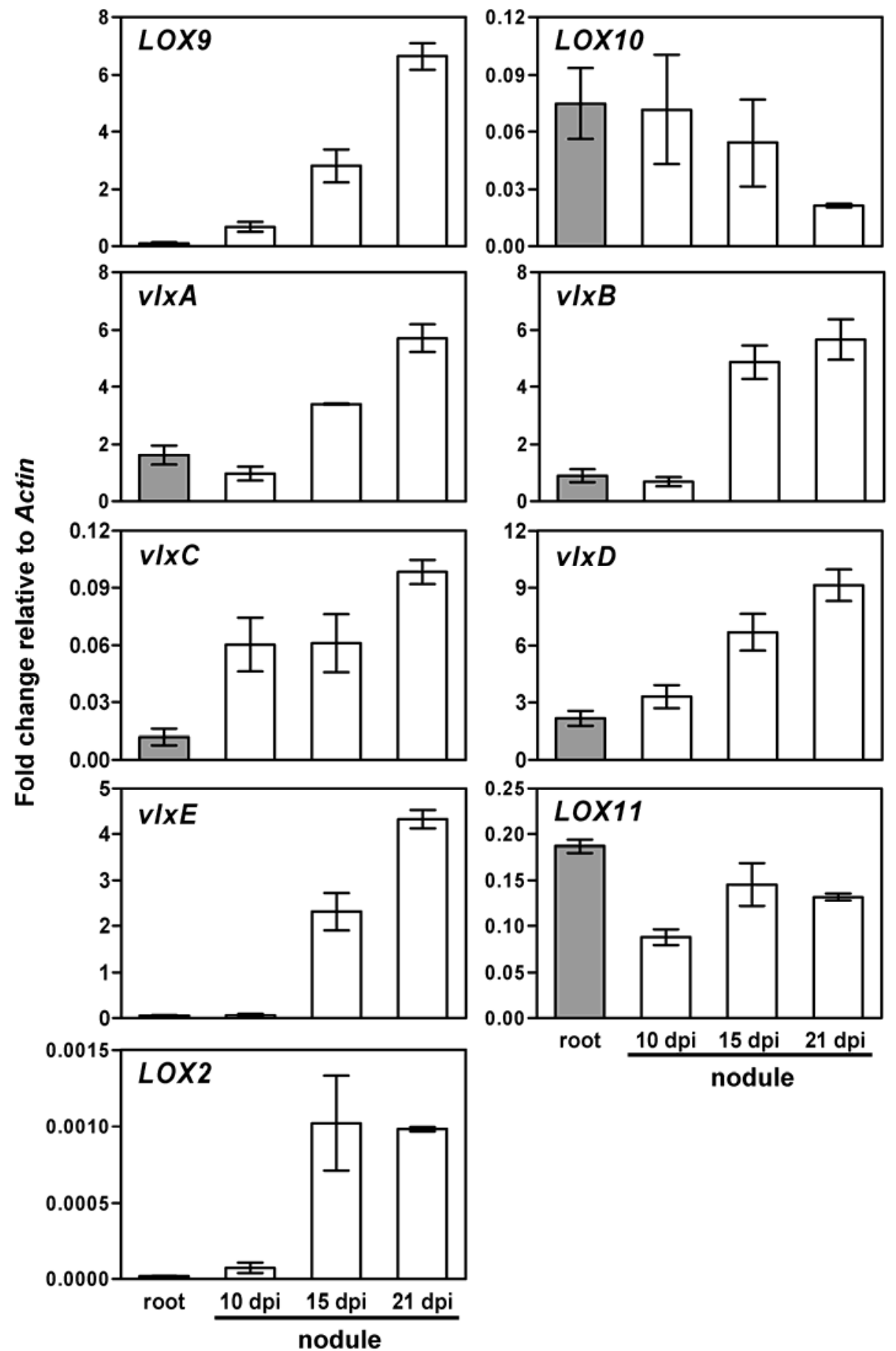

Fig. 3. Time-course expression analysis of soybean lipoxygenases (LOXs) in developing nodules. Expression of the LOX genes was analyzed by quantitative real-time polymerase chain reaction of RNA isolated from nodules of wild-type plants at 10, 15, and 21 days postinoculation (dpi). Uninoculated root at 10 days post-treatment was used for comparison. Error bars indicate the standard error of the data resulting from three independent experiments. 
vascular bundles (data not shown), suggesting that LOX9 expression is associated with vascular development. Root cortex also was stained closest to the root tips, whereas no staining was observed in these cells distant from the root tips. Cross sections of the roots showed that the staining in the root vasculature was specific to the phloem (Fig. 5B and C). In nodules, GUS activity was detected around the tip of developing vascular bundles and, intermittently, in the outer parenchyma cells in the young developing nodules (Fig. 5J). In more mature nodules, the GUS activity in these areas was less prominent (Fig. 5K) and primarily was restricted to the developing lenticels (Fig. 5I and L). Although the intensity of staining varied slightly, the qualitative staining patterns were similar among independent hairy roots. No obvious differences in staining were observed between hairy roots derived from wild-type and $n t s$ plants or inoculated and uninoculated roots (other than nodule staining in the inoculated roots). In addition, no background staining was present in the hairy roots lacking the transgene, indicating that the staining is due to the insertion of the promoter::GUS construct into the soybean genome.

\section{Analysis of LOX RNAi transgenic hairy roots.}

To investigate the potential function of LOX in nodule development, we attempted to reduce LOX gene expression in transgenic hairy roots. Transgenic hairy roots were generated that contained an RNAi construct which targeted LOX9. Although these LOX9 RNAi roots exhibited significantly reduced levels of LOX9 gene expression (data not shown), there was no detectable effect on root or nodule development (data not shown). To further examine the potential role of LOXs in nodulation, we constructed transgenic hairy roots that carry RNAi constructs for both LOX9 and LOX10. The qRT-PCR analysis showed that the expression of both target genes was significantly reduced in the double $L O X$ ( $L O X 9$ and $L O X 10$ ) RNAi hairy roots relative to the vector-alone controls (Fig. 6A). Double $L O X$ RNAi hairy roots showed approximately 99 and $95 \%$ reduced expression of LOX9 and LOX10, respectively. Although the target sequences for the two genes had only limited sequence similarity to the other soybean $L O X \mathrm{~s}$, expression of $v l x A$ to $-E$ also was found to be significantly suppressed (approximately 97\%) in double LOX RNAi hairy roots (Fig. 6A). Expression of the less abundant $L O X 11$ was not significantly affected by the double $L O X$ RNAi constructs (Fig. 6A), and expression of two seed LOXs (LOX2 and $L O X 3$ ) was barely detectable in both the control and RNAi transgenic roots (data not shown). Overall, the observed LOX expression was reduced by approximately $95 \%$ in the double $L O X$ RNAi hairy roots. Interestingly, despite the dramatic reduction in LOX gene expression, no significant differences in nodule development were observed between the control and the double LOX RNAi hairy roots (Fig. 6B). Nodules on the RNAi hairy roots were indistinguishable from the control nodules with respect to their gross morphology and accumulation of leghemoglobin (data not shown). In addition, rhizobia-inoculated composite plants (consisting of a wild-type shoot and either double LOX RNAi or vector control transgenic roots) grown using a nitrogen-free nutrient solution did not display any symptoms of nitrogen stress, indicating that reduced LOX expression did not significantly impair nodule function (data not shown). These data suggest that the functions of different LOXs that are associated with nodule development are not essential for the development of this symbiotic organ.

\section{DISCUSSION}

We used transcriptional profiling to identify genes that may function during soybean nodule development. Our data showed that early soybean nodulation was associated with the transcrip- tional control of genes involved in various processes such as defense, metabolism, transcriptional regulation, oxidation, and iron storage. Similar genes from L. japonicus and M. truncatula also have been associated with nodule development, indicating that these candidates may function in processes that are of general importance during legume nodulation (Colebatch et al. 2002; Kouchi et al. 2004; Lohar et al. 2006). One such class of genes are those encoding the enzyme LOX. We found that soybean nodules expressed a variety of different LOXs. Detailed expression analyses of $L O X 9$ indicated that it may function in the development of specific tissues such as the vasculature and nodule lenticels. Despite the complex LOX expression in developing nodules, our RNAi studies indicated that many of these LOXs are not likely to be essential for the development or function of this symbiotic organ.

In soybean, eight LOXs have been characterized. This consists of three LOXs that are primarily expressed in seed (LOX1, 2 , and 3) and five other LOXs that are present in the vegetative tissues (vegetative LOX: VLXA, B, C, D, and E). Prior to the work described here, it was not known which, if any, of these LOXs were expressed in soybean nodules. Our data showed that nodules expressed very high levels of all the vegetative LOXs (vlXA to $-E$ ), as well as three novel soybean LOXs, LOX9 to -11 . Previous studies on these vegetative LOXs have suggested that different members of the LOX family likely have distinct biological functions (Dubbs and Grimes 2000; Fischer et al. 1999). For example, VLXD is thought to act as a major storage protein in leaves, whereas VLXA, -B, and -C are thought to act as active enzymes during assimilate retranslocation through the paraveinal mesophyll cell layer (Fischer et al. 1999). Based on the sequence diversity of LOXs found in nodules, it would appear that these enzymes may participate in various roles in this organ.

Sequence analysis of LOX9 and LOX10 showed that they are more similar to LOXs from other legume species than to one another, suggesting that they may be functionally divergent. LOX10 appeared most similar to a Medicago LOX in which no prior expression studies or functional data is available. LOX9 showed high sequence similarity to PvLOX2, suggesting that these two proteins may be orthologs. In general, $P v L O X 2$ was reported to be highly expressed in young, devel-

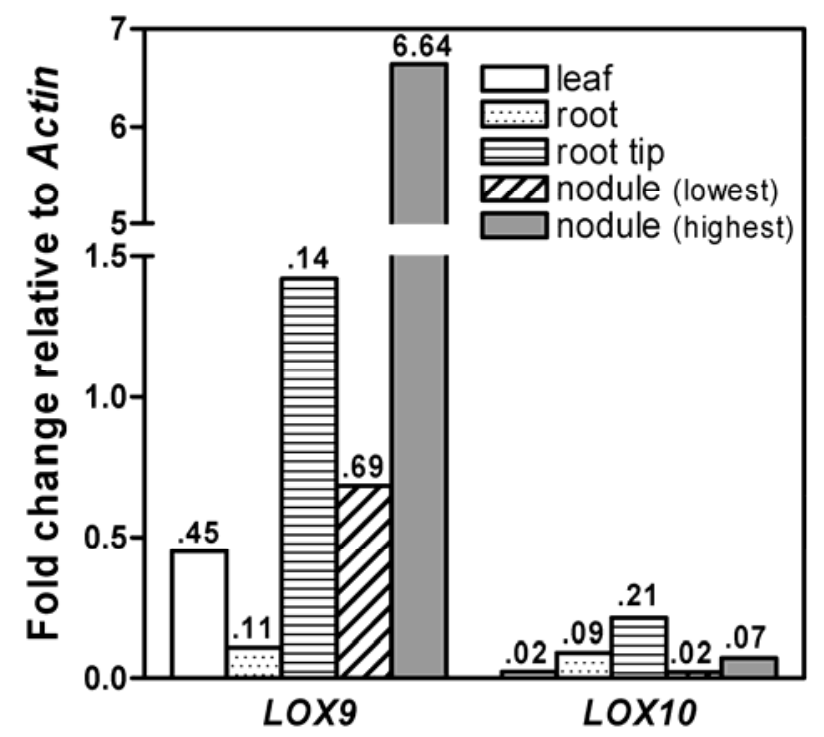

Fig. 4. Expression of lipoxygenase 9 (LOX9) and 10 (LOX10) in different tissues. The expression values for leaf and root represent the averages taken from the wild-type uninoculated plants in the time-course studies. The expression in nodules is taken from the lowest and the highest expression values observed in the time-course study. 
oping nodules (14 to $16 \mathrm{dpi}$ ) based on Northern blot analysis (Porta et al. 1999). The expression of this gene decreased with nodule age and became almost undetectable at 21 dpi. Immunolocalization of PvLOX2 revealed that this protein is present in the nodule parenchyma and in the noninfected cells of the central nodule tissues at 14 to 19 dpi (Porta et al. 1999). The presence of PvLOX2 in noninfected parenchyma cells, in which a number of proteins involved in plant defense (i.e., chitinases [Staehelin et al. 1992] and extensins) are found (Perlick et al. 1996), suggested a role for this LOX in nodule defense against possible pathogen invasion. In addition, the expression of this protein in young nodules suggested that PvLOX2 may be involved in cell elongation.

The expression data on $P v L O X 2$ provides limited information regarding the cellular expression of this gene during development. Analyses of $L O X 9$ expression, utilizing a promoter: $G U S$ fusion in transgenic hairy roots, have allowed for a more detailed assessment of $L O X$ expression in developing roots and nodules. Results from these studies indicated that $L O X 9$ expression was relatively dynamic and was not restricted to a specific cell or tissue type. As shown for PvLOX2, LOX9 expression also was present in the outer parenchyma cells of the young developing nodules; however, this expression was relatively weak and disappeared in older nodules. Similarly, the overall LOX9 promoter::GUS activity in both roots and nodules indicated that the cellular expression of this gene was associated with the development of specific cell types (discussed below). These data suggest that LOX9 expression in parenchyma cells may function in cell growth associated with an increase in nodule size rather than an involvement in a defense mechanism as suggested for PvLOX2.

Although it was not reported for PvLOX2, strong LOX9 promoter activity was detected in other types of cells and tissues. This includes root tips, root vasculature (specifically, in the phloem), and nodule lenticels. Root tips showed very high LOX9 promoter activity, which is in agreement with the high

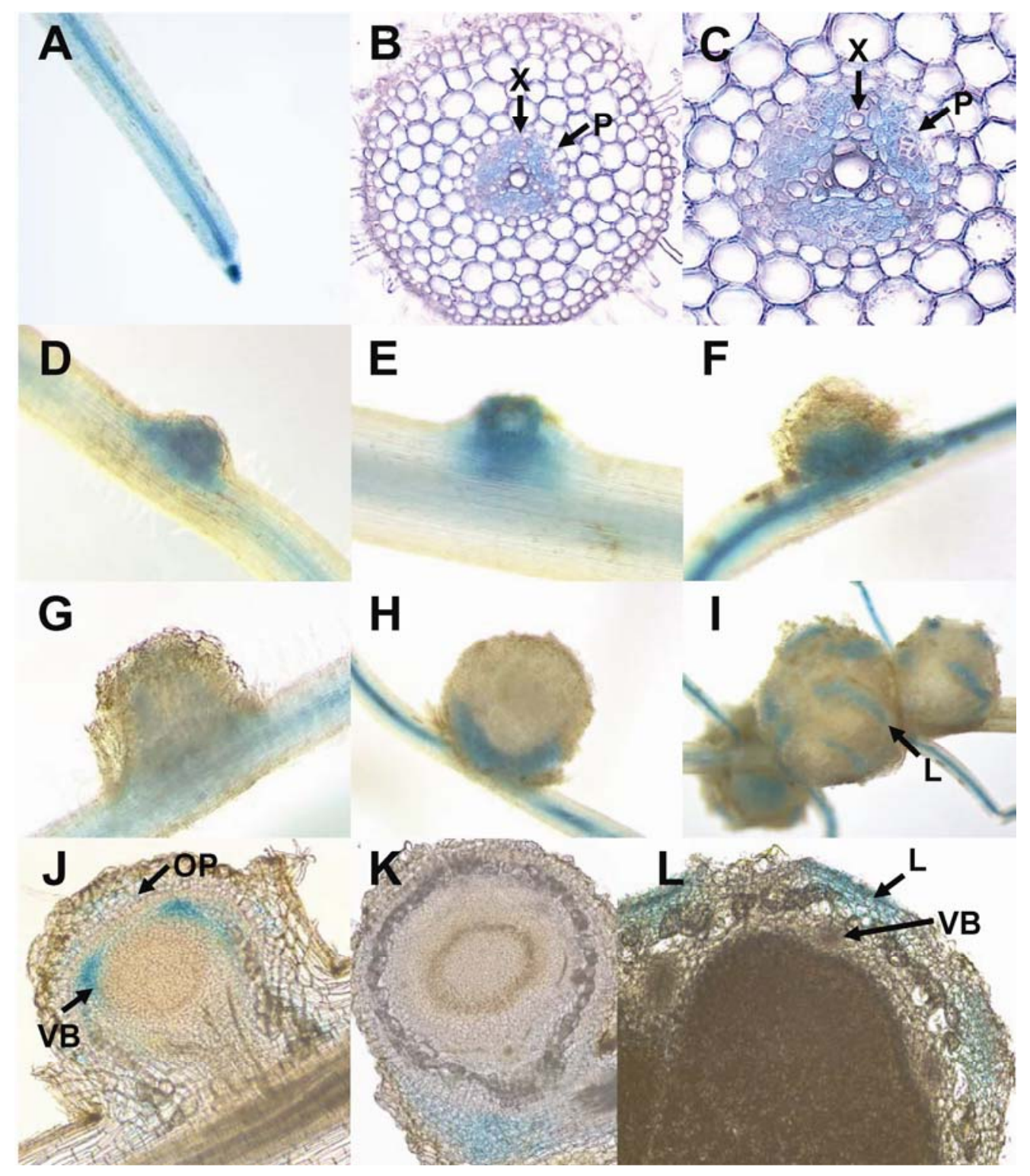

Fig. 5. $\beta$-Glucuronidase (GUS) staining of hairy roots containing the GmLOX9 promoter::GUS construct. A, GUS activity is strong at the root tip and the root vasculature. $\mathbf{B}$ and $\mathbf{C}$, Cross section of the root revealed that GUS activity was specific to the phloem. $\mathbf{D}$ through $\mathbf{I}$, The pattern of GUS activity in nodules differed depending on their developmental stage $\mathbf{D}$, Nodule primordia showed general GUS activity and this staining became restricted to $\mathbf{E}$ through $\mathbf{G}$, the developing vasculature and, subsequently, $\mathbf{H}$ and $\mathbf{I}$, the lenticels. J, Longitudinal section of nodule showing GUS activity in the outer parenchyma and the developing vascular bundles, $\mathbf{K}$, which disappeared in more mature nodules. $\mathbf{L}$, Cross section of mature nodule showing GUS activity specific to the site of lenticel formation. $\mathrm{P}=$ phloem, $\mathrm{X}=$ xylem, $\mathrm{L}=$ lenticel, $\mathrm{OP}=$ outer parenchyma cells, and $\mathrm{VB}=$ vascular bundle. 
expression of $L O X 9$ observed by qRT-PCR. Within the root tip, the root cap and, likely, the zone of elongation showed the strongest promoter activity. This indicates that LOX9 expression is strongest in rapidly growing tissues, as is found for many other LOXs (Siedow 1991), but also is present in the differentiating cells and in a region where cell turnover occurs.

The subcellular localization of LOXs can provide a clue to their physiological function. For example, soybean VLXs that act as storage proteins are known to accumulate in vacuoles of the bundle sheath (BS) and paraveinal mesophyll (PVM) cells of the leaf in response to sink limitation (i.e., depotting and shoot removal) (Tranbarger et al. 1991). Whereas other VLXs that accumulate in the same type of cells but are localized to the cytosol are thought to function as active enzymes in lipid metabolism or membrane reorganization during assimilate translocation through the PVM cell layer (Fischer et al. 1999). LOXs that act in mobilization of lipids during germination are associated specifically with the lipid bodies (Feussner et al. 2001) and those that have a role in JA synthesis are localized in the chloroplast (Bell and Mullet 1993). Sequence characterization of both LOX9 and LOX10 indicates that they are members of type 1-LOXs which are a group of LOXs that lack an Nterminal plastidic transit peptide. Therefore, these LOXs are not likely involved in JA synthesis but may be involved in processes such as lipid metabolism or membrane modification.

LOX9 promoter activity in the developing vascular bundle of young nodules and the phloem of the root vasculatures suggests that $L O X 9$ may be associated with vascular development. As described above, LOXs that act as storage proteins are also present in association with vascular tissue, specifically at the BS and the PVM cells (Tranbarger et al. 1991). In addition, the presence of LOX in phloem companion cells of the nodule vascular tissue has been reported in pea (Gardner et al. 1996). The study of pea LOX in nodules has suggested that this LOX also may function as a storage protein. However, unlike LOXs which are localized to the vacuole and have a proposed function as storage proteins in PVM cells, the LOX in pea is localized to the cytoplasm (Gardner et al. 1996). Vascular expression of $L O X 9$ appeared to be stronger in the young roots and nodules and much weaker or absent in the mature primary roots and nodules, suggesting that the expression of this gene is dependent on the developmental stage of these tissues. Taken together, LOX9 promoter activity at the site of developing nodule vascular bundles and in the young root vasculature more likely is due to the action of LOX9 in development or differentiation of the vascular tissue, rather than functioning as a storage protein as suggested for other LOXs.

The most intriguing finding for $L O X 9$ promoter activity was the observed expression at the nodule surface in the developing lenticels. To date, expression of LOX has not been reported in this region. Nodule lenticels are ridges formed at the surface of the nodules that allow free movement of gases $\left(\mathrm{N}_{2}, \mathrm{O}_{2}, \mathrm{CO}_{2}\right.$, and so on) inside and out of the nodules (Pankhurst and Sprent 1975). Microscopic analysis showed that these structures occur directly opposite to the vascular traces in the nodule cortex (Pankhurst and Sprent 1975). Enhanced lenticel development in association with low $\mathrm{O}_{2}$ availability in a case such as flooding is reported in a number of legume species (Batzli and Dawson 1999; Pankhurst and Sprent 1975; Thomas et al. 2005). Expression of LOX9 in the young developing lenticels suggests that this LOX may function in the development of these nodule structures. Further analyses showed that LOX9 promoter activity was still present in the lenticels of fully mature nodules (approximately 7 weeks postinoculation), although the intensity of staining was weaker than that observed in younger nodules.

The expression analyses showed that a number of LOXs (at least eight) may be involved in nodule development. In addition, many of these LOXs displayed very high levels of expression. RNAi constructs targeted to $L O X 9$ and $L O X 10$ effectively knocked down the expression of virtually all of these $L O X s$ in transgenic roots. Interestingly, however, reducing the observed LOX expression by approximately $95 \%$ did not result in any detectable phenotype. One explanation for this finding is that LOXs are not essential for nodule development under the conditions utilized in these studies. We cannot discount the possibility, however, that the small amount of residual $L O X$ expression is sufficient to fulfill the normal function of this enzyme. In addition, it also is possible that there are other functionally related $L O X$ s expressed in nodules that are not affected by the RNAi. This possibility would seem unlikely, however, because the RNAi was very effective in silencing the expression of a
A

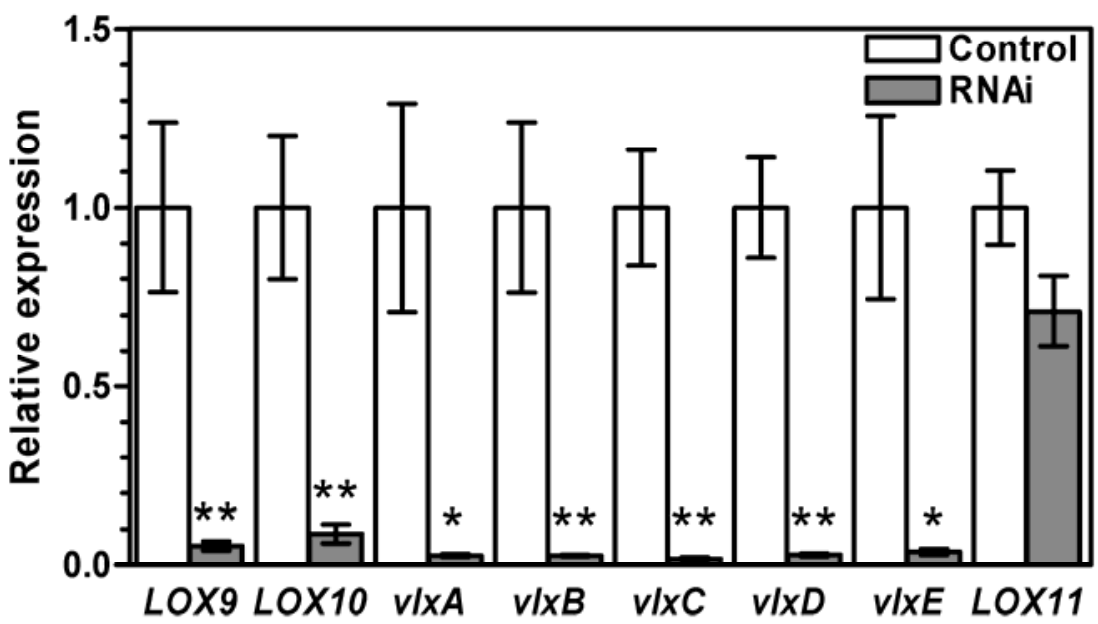

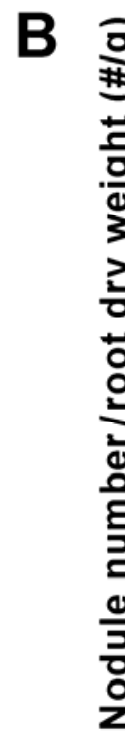

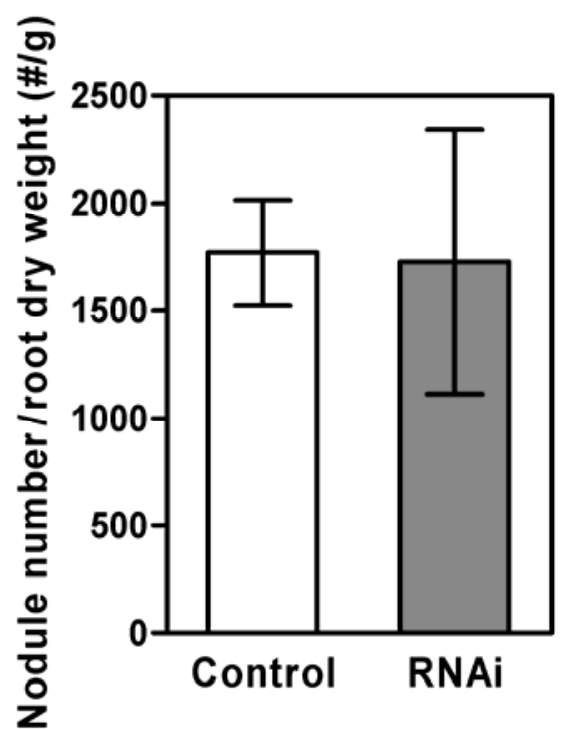

Fig. 6. Double lipoxygenase ( $L O X)$ ( $L O X 9$ and $L O X 10$ ) RNAi hairy root analysis. A, Expression of soybean $L O X s$ at 3 weeks postinoculation and B, nodule number per root dry weight (grams) in control versus double $L O X$ RNAi transgenic hairy roots $(n>6)$. Error bars represent the standard error for each group. Asterisks indicate statistically significant differences between control and double $L O X$ RNAi hairy roots (student's $t$ test, $* *$ and $*=P<0.01$ and 0.05 , respectively). 
variety of different $L O X$ s. It is doubtful that LOXs varying significantly in sequence would be functionally redundant.

In conclusion, this study analyzed the function of LOX in nodulation. We identified two novel soybean LOX genes, $L O X 9$ and $L O X 10$, that are expressed in nodules and potentially may be involved in the development of this symbiotic organ. The complexity of $L O X$ expression in nodules indicates that they may perform a variety of different functions. However, the RNAi studies suggest that the specific function of many of these LOXs is not likely to be essential for nodulation.

\section{MATERIALS AND METHODS}

\section{Plant growth and Bradyrhizobium spp. inoculation.}

Wild-type soybean seed (G. $\max$ (L.) Merr. cv. Bragg) and its near-isogenic supernodulating mutants (nts1007 and nts382) (Carroll et al. 1985a and b; Searle et al. 2003) were surface sterilized by overnight chlorine gas treatment in a sealed chamber. Root tissue used for Affymetrix microarray analysis was obtained from 8-day-old seedlings grown in growth pouches (Mega International, West St. Paul, MN, U.S.A.). Germination and seedling growth was carried out in a Conviron maintained at day and night temperatures of 28 and $25^{\circ} \mathrm{C}$, respectively, with $80 \%$ humidity and a 16 -h photoperiod. The root tip was marked at the time of treatment (rhizobia inoculation or mock inoculation) and, at $5 \mathrm{dpt}$, a root segment (from $15 \mathrm{~mm}$ above and $5 \mathrm{~mm}$ below the root tip mark) was isolated from approximately 18 plants/replicate. Biological replicates were grown at completely independent times from one another. Other plants were grown in vermiculite in a temperature-controlled glass house (light and darkness, 16 and $8 \mathrm{~h}$ and temperature, 28 and $25^{\circ} \mathrm{C}$, respectively). These plants were watered at least once a day and treated with $\mathrm{B} \& \mathrm{D}$ nutrient solution (Broughton and Dilworth 1971) once a week. Bradyrhizobium japonicum CB1809 was grown in YMB medium (Vincent 1970) at $28^{\circ} \mathrm{C}$ for 3 days and diluted with water to an optical density at $600 \mathrm{~nm}$ of approximately 0.1 just before inoculation.

\section{Affymetrix GeneChip hybridization and candidate gene identification.}

Approximately $7.5 \mu \mathrm{g}$ of total RNA was labeled using the Affymetrix one-cycle cDNA synthesis kit (Millennium Sciences), and the cDNA subsequently was cleaned using the Affymetrix GeneChip sample cleanup kit. The in vitro transcription (IVT) amplification and biotin-labeling of cRNA was performed using the Affymetrix IVT labeling kit, and cRNA subsequently was cleaned using the GeneChip sample cleanup kit. A total of $20 \mu \mathrm{g}$ of labeled cRNA was fragmented to the 50- to 200-bp size range and quality control checked with a Bioanalyser 2100 using the NanoChip protocol. Hybridization to the Affymetrix GeneChip soybean genome array was performed as described in the Affymetrix technical analysis manual. The GeneChips were washed and stained with streptavidin-phycoerythrin using the Affymetrix fluidics station 450 and scanned using the Affymetrix GeneChip scanner 3000.

Data analysis was performed by pairwise comparisons of GeneChips using dCHIP (Li and Wong 2001). Comparisons were performed to determine a lower $90 \%$ confidence bound (LCB) value, which represents a conservative estimate of the fold-change. To identify genes that may be differentially expressed in the root in response to rhizobia inoculation, the following four comparisons were performed: wild-type inoculated versus wild-type uninoculated root segments at $5 \mathrm{dpt}$ (two biological replicates) and nts 1007 inoculated versus wild-type uninoculated root segments at $5 \mathrm{dpt}$ (two biological replicates).
Genes that displayed an LCB value of twofold or higher for all four comparisons were identified.

\section{RNA extraction and cDNA synthesis.}

Soybean RNA was extracted using TRIZOL reagent (Invitrogen, Carlsbad, CA, U.S.A.) following the manufacturer's protocol. To remove contaminating DNA, approximately $1 \mu \mathrm{g}$ of RNA was treated with $1 \mathrm{U}$ of DNaseI (Fermentas, Burlington, Canada) at $37^{\circ} \mathrm{C}$ for $40 \mathrm{~min}$. These reactions were terminated by the addition of $1 \mu \mathrm{l}$ of $25 \mathrm{mM}$ EDTA (Invitrogen) and incubation at $65^{\circ} \mathrm{C}$ for $10 \mathrm{~min}$. The cDNA synthesis was carried out according to the manufacturer's instructions using approximately $0.5 \mu \mathrm{g}$ of DNase-treated RNA, oligo(dT) primer, and Superscript III reverse transcriptase (Invitrogen). The cDNA synthesis was verified by PCR using intron-spanning primers (5'-GGTCGCACAACTGGTATTGTATTG-3' and 5'-CTCAG CAGAGGTGGTGAACA-3') to soybean actin (V00450).

\section{Cloning full length $L O X$ cDNAs.}

The 5' RACE was performed using the FirstChoice RNA ligase-mediated (RLM)-RACE kit (Ambion, Austin, TX, U.S.A.) to clone the 5' unknown region of LOX9 and LOX10. The 5' RACE cDNA template was prepared using $10 \mu \mathrm{g}$ of RNA from $n t s 1007$ root tissue harvested at 5 dpi following the manufacturer's instructions.

Amplification of the 5' unknown region from the known 3' end was performed by nested PCR using the cDNA template prepared above. Sequence-specific outer and inner PCR primers used to amplify each $L O X$ gene are as follows: $L O X 9$ outer primer 5'-GCTGTTAGGAATGCCTCTGCAA-3', LOX9 inner primer 5'-CCTCTGCAAGTCAACCCTTC-3', LOX10 outer primer 5'-GCAGTGGGAAGGTCATTGAT-3', and LOX10 inner primer 5'-CTCAGTGCCTGTTCCACAGA-3'. Purified PCR products were ligated with pCR2.1-TOPO using the TOPO-TA cloning kit (Invitrogen) following the manufacturer's instructions and sequenced through the Australian Genome Research Facility, Brisbane. Sequences for the fulllength $L O X$ cDNAs were verified by sequencing independent PCR products that were amplified using the proofreading polymerase i-Pfu (iNtRON).

\section{Cloning of $L O X 9$ promoter region and promoter::GUS fusion construction.}

The LOX9 BAC clone (23M24) was identified by BLASTN of the genomic survey sequences database using the nucleotide sequence for LOX9. BAC DNA was purified using the Qiagen plasmid midikit protocol modified for BAC DNA purification. Purified BAC DNA was used as a template for sequencing via primer walking to obtain approximately $2 \mathrm{~kb}$ upstream of the LOX9 TSS.

The $L O X 9$ promoter activity was studied using two different promoter::GUS constructs. Approximately $800 \mathrm{bp}$ and $2 \mathrm{~kb}$ of sequence $5^{\prime}$ of the LOX9 TSS were amplified with i-Pfu using primers containing engineered restriction enzyme (RE) sites for cloning into the binary vector pCAMBIA1305.1 (GenBank accession number AF354045). Two promoters were amplified using forward primers with an engineered HindIII site that attach either -773 or $-1,966$ bp of LOX9 TSS (5'-aagcttCAGC ATAGTAGTTGATTCATATATTTAATGTGTT-3' or 5' ${ }^{\prime}$-aagcttG CATAGTTAAAACTTGTGGTCATGCAG-3' respectively), and reverse primers 5'-ccatggTTGCTAGCTTGCTACTTCAACAC AACAC-3' ( $N c o$ I) and 5'-agatctacCATCTTTGCTAGCTTGCT ACTTCAACAC-3' (BglII and additional two nucleotides; underlined). Prior to cloning into pCAMBIA1305.1, PCR products were cloned into pCR2.1-TOPO and sequence verified. Using the engineered RE sites in the PCR primers, these promoter regions were subcloned from pCR2.1-TOPO into pCAMBIA- 
1305.1 at the $5^{\prime}$ end of the GUS gene. The LOX9pr::GUS constructs were electroporated into Agrobacterium rhizogenes K599.

\section{Sequence analysis.}

Protein sequence identity and similarity between different LOXs were obtained by BLAST analysis. Sequence alignments were performed using ClustalW from the European Bioinformatics Institute (EMBL-EBI). All sequences were gathered from the GenBank database (National Center for Biotechnology Information). In addition, patterns, profiles, and motifs prediction of the two LOX proteins were performed with the ScanProsite tool under the Expert Protein Analysis System (ExPASY) proteomics server. The possible subcellular localization of the two LOXs was analyzed using the TargetP 1.1 server (Centre for Biological Sequence Analysis, Technical University of Denmark) which utilizes the prediction method of Emanuelsson and associates (2000). The prediction of the potential cis-acting regulatory elements within the $L O X 9$ promoter region was performed by using the Signal Scan program of plant cis-acting regulatory DNA elements (PLACE) database.

\section{LOX RNAi vector construction.}

For constructing the RNAi vectors, 478 bp from $L O X 9$ and 383 bp from the LOX10 cDNA sequence were selected as targets. These sequences were amplified with two primer sets containing different RE sites for subsequent cloning of the target sequences into the RNAi vector pHannibal (CSIRO; GenBank accession number AJ311872). The first primer sets used to amplify the target sequence for each gene were $5^{\prime}$-ctcgagAA AAGGAGAGCGCAAGGAATATGATAGGA-3' (XhoI) and 5'-ggtaccAACTTTGATGACATGAGGTGGTGGAAACTT-3' (KpnI) for $L O X 9$, and 5'-ctcgagACAGTGGTGTTGATGCGTA AGAATGTGTT-3' (XhoI) and 5'-ggtaccAACGTCTTCAAGA GTCAAACTCACAAGGAA-3' (KpnI) for LOX10. XhoI and $K p n I$ sites were replaced with $X b a I$ and HindIII sites, respectively, for the second primer sets. The target sequence for each gene was amplified with i-Pfu using cDNA template. The resulting PCR products were cloned into pCR2.1-TOPO and sequence verified prior to cloning into pHannibal.

The RNAi constructs were excised from the pHannibal vector using NotI digestion and subcloned into phosphatase-treated binary integration vectors. Integration vectors p15SRK2 and pMIKCK1 were used for $L O X 9$ RNAi and LOX10 RNAi constructs, respectively. Integration vectors containing the RNAi construct were electroporated into Escherichia coli and selected on Luria-Bertani (LB) medium based on antibiotic resistance (p15SRK2; spectinomycin ${ }^{\mathrm{r}}$ and pMIKCK1; kanamycin ${ }^{\mathrm{r}}$ ) and lac $Z$ expression. Finally, the p15SRK2-LOX9 RNAi construct and pMIKCK1-LOX10 RNAi construct were purified from the selected cells and transformed into $E$. coli $\mathrm{HB} 101$ for triparental mating.

\section{qRT-PCR.}

Primers used for qRT-PCR were designed using Primer Express software (v. 2.0; Applied Biosystems, Foster City, CA, U.S.A.). The sequences for forward and reverse primer for each gene were 5'-CATTTCTGCCTGGGCCATT-3' and 5'-TGAAA ACCCACCCCTTGTAAAC-3' for $L O X 9,5^{\prime}$-AAACTCGCCAA GAGTTGATTGAA-3' and 5'-AAGGGCTGAAGCAGTCCAA A-3' for LOX10, 5'-CAGTGTTGGAGGGATCGTTGA-3' and 5'-GATTTTGGTGGCTGCAAAAGTAAG-3' for $v l x A, 5^{\prime}$-TCT GAGCGTGGTTCACCCTATTT-3' and 5'-GCTTGATCGGTG AAAACCCAAT- $3^{\prime}$ for $v l x B, 5^{\prime}$-CAATCATTGGAGGCTCTAG CAA-3' and 5'-TATCTCGCCTGGTTTCTCACTGT-3' for vlxC, 5'-AACTGAAGATCTCATTCAATCATGCT-3' and $5^{\prime}-\mathrm{G}$ GATTAAGCCCCCATAAGGATATT-3' for vlxD, 5'-CATTGG AACCGGCATTAACAT-3' and 5'-CATCAGCCTTGGTGGCA
CTA-3' for vlxE, 5'-AGCCATTGGCAGCATTTGAG-3' and 5'GGGATTCCCTTGCCAGTTAGTC-3' for $L O X 11,5^{\prime}$-ACAATG ATCAAAGTCTCTCCAATCG-3' and 5'-AAGTAGACCACAT GCTCCCTTAGATAG-3' for $L O X 2$, and 5'-TGGCCTTGCTCG GTTATCAC-3' and 5'-TGAGGGCACGATGGATCCT-3' for LOX3. Reactions were set up with SYBR green (Applied Biosystems) in a 384-well plate using the Eppendorf epMotion 5075 Robotics System and run on an ABI Prism 7900 Sequence detection system (Applied Biosystems). Each plate contained reverse transcription negative (RT-) controls for some of the cDNA samples and no template (water) controls. All qRT-PCR reactions were carried out in duplicate and expression of actin (V00450) was used as a reference. The qRT-PCR was run using an annealing temperature of $60^{\circ} \mathrm{C}$. A dissociation stage was added at the end of the cycle in order to assess the specificity of the PCR.

\section{Triparental mating and transgenic hairy root production.}

Triparental mating was performed to transfer and integrate the transgene from HB101 into the A. rhizogenes Ri plasmid by homologous recombination due to the specific sequence on the integration vector. A. rhizogenes K599, E. coli HB101 containing pRK2013 (Helper R), and those containing p15SRK2LOX9 RNAi or p15SRK2 alone (vector control) were grown on plates with appropriate antibiotics. For each type of bacteria, a half-inoculation loop full $(0.5 \mathrm{~cm}$ in diameter $)$ of growing bacteria was scraped from the plates, mixed together in 1 $\mathrm{ml}$ of $\mathrm{LB}$, and plated on LB plates without antibiotic in a form of droplet. These plates were incubated at $28^{\circ} \mathrm{C}$ overnight and the resulting bacteria were plated on minimal (MIN) medium with appropriate antibiotics. Individual colonies were streaked on fresh MIN plates and integration of the vector-alone control and the RNAi construct into the $A$. rhizogenes Ri plasmid were confirmed by PCR. To obtain $A$. rhizogenes with the double LOX (LOX9 and LOX10) RNAi construct and its respective control, A. rhizogenes K599 carrying p15SRK2-LOX9 RNAi or p15SRK2 (vector alone) were mated with E. coli HB101 containing pCU101 (Helper C) and those containing pMIKCK1-LOX10 RNAi or pMIKCKI vector alone, respectively. This was followed by the procedure described above. $A$. rhizogenes-mediated hairy root transformation was performed as previously described (Kereszt et al. 2007).

\section{GUS histochemical assay.}

Transgenic hairy roots carrying the $L O X 9$ pr::GUS construct were assessed for GUS activity as described in Nontachaiyapoon and associates (2007). Samples chosen for sectioning were embedded in 3\% agarose and sectioned to $100-\mu \mathrm{m}$ thickness using a vibratome (Lancer Series 1000; Ted Pella, Irvine, CA, U.S.A.).

\section{LOX RNAi transgenic hairy root analysis.}

Bradyrhizobium spp.-inoculated transgenic hairy roots from wild-type plants were examined at 3 weeks postinoculation. Nodule number, root length, and root morphology were recorded as a measurement of the phenotype for each transgenic hairy root. Following the phenotypic analyses, each root was frozen immediately with liquid nitrogen. These root samples then were subjected to RNA extraction followed by cDNA synthesis to measure the expression level of the two LOXs by qRT-PCR. The remaining root powder was dried and weighed as a measurement for root dry weight.

\section{ACKNOWLEDGMENTS}

The soybean BAC clone was obtained from the Clemson University Genomics Institute (CUGI; Clemson, SC, U.S.A.). The vector pHannibal was 
obtained from CSIRO. We would like to thank B. Simpson (School of Molecular and Microbial Science, The University of Queensland) for help with qRT-PCR and A. Kereszt (CILR, The University of Queensland) for help with triparental mating. Financial support came from the ARC Centre of Excellence program, the University of Queensland Strategic Fund, the BACS Faculty, and the Queensland Government Smart State Initiative.

\section{LITERATURE CITED}

Bateman, A., and Sandford, R. 1999. The PLAT domain: A new piece in the PKD1 puzzle. Curr. Biol. 9:R588-R590.

Batzli, J. M., and Dawson, J. O. 1999. Development of flood-induced lenticels in red alder nodules prior to the restoration of nitrogenase activity. Can. J. Bot. 77:1373-1377.

Bell, E., and Mullet, J. E. 1993. Characterization of an Arabidopsis-lipoxygenase gene responsive to methyl jasmonate and wounding. Plant Physiol. 103:1133-1137.

Bhuvaneswari, T. V., Turgeon, B. G., and Bauer, W. D. 1980. Early events in the infection of soybean (Glycine max L. Merr.) by Rhizobium japonicum: I. Localization of infectible root cells. Plant Physiol. 66:10271031

Boyington, J. C., Gaffney, B. J., and Amzel, L. M. 1990. Crystallization and preliminary-X-ray analysis of soybean lipoxygenase-1, a nonheme iron-containing dioxygenase. J. Biol. Chem. 265:12771-12773.

Brash A. R. 1999. Lipoxygenases: Occurrence, functions, catalysis, and acquisition of substrate. J. Biol. Chem. 274:23679-23682.

Broughton, W. J., and Dilworth, M. J. 1971. Control of leghaemoglobin synthesis in snake beans. Biochem. J. 125:1075-1080.

Caetano-Anollés, G., and Gresshoff, P. M. 1991. Excision of nodules induced by Rhizobium meliloti exopolysaccharide mutants releases autoregulation in alfalfa. J. Plant Physiol. 138:765-767.

Calvert, H. E., Pence, M. K., Pierce, M., Malik, N. S. A., and Bauer, W. D. 1984. Anatomical analysis of the development and distribution of Rhizobium infections in soybean roots. Can. J. Bot. 62:2375-2384.

Carroll B. J., McNeil D. L., and Gresshoff P. M. 1985a. Isolation and properties of soybean [Glycine $\max (\mathrm{L}$.) Merr.] mutants that nodulate in the presence of high nitrate concentrations. Proc. Natl. Acad. Sci. U.S.A. 82:4162-4166.

Carroll, B. J., McNeil, D. L., and Gresshoff P. M. 1985b. A supernodulation and nitrate-tolerant symbiotic (nts) soybean mutant. Plant Physiol. 78:34-40.

Chen, X. S., Kurre, U., Jenkins, N. A., Copeland, N. G., and Funk, C. D. 1994. cDNA cloning, expression, mutagenesis of C-terminal isoleucine, genomic structure, and chromosomal localizations of murine 12-lipoxygenases. J. Biol. Chem. 269:13979-13987.

Colebatch, G., Kloska, S., Trevaskis, B., Freund, S., Altmann, T., and Udvardi, M. K. 2002. Novel aspects of symbiotic nitrogen fixation uncovered by transcript profiling with cDNA arrays. Mol. Plant-Microbe Interact. 15:411-420.

Croft, K. P. C., Juttner, F., and Slusarenko, A. J. 1993. Volatile products of the lipoxygenase pathway evolved from Phaseolus vulgaris (L.) leaves inoculated with Pseudomonas syringae pv. phaseolicola. Plant Physiol. 101:13-24.

Delves, A. C., Mathews, A., Day, D. A., Carter, A. S., Carroll, B. J., and Gresshoff P. M. 1986. Regulation of the soybean-Rhizobium nodule symbiosis by shoot and root factors. Plant Physiol. 82:588-590.

Dubbs, W. E., and Grimes, H. D. 2000. Specific lipoxygenase isoforms accumulate in distinct regions of soybean pod walls and mark a unique cell layer. Plant Physiol. 123:1269-1279.

Emanuelsson, O., Nielsen, H., Brunak, S., and von Heijne, G. 2000. Predicting subcellular localization of proteins based on their N-terminal amino acid sequence. J. Mol. Biol. 300:1005-1016.

Esseling, J. J., Lhuissier, F. G. P., and Emons, A. M. C. 2003. Nod factorinduced root hair curling: Continuous polar growth towards the point of nod factor application. Plant Physiol. 132:1982-1988.

Feussner, I., and Wasternack, C. 2002. The lipoxygenase pathway. Annu. Rev. Plant Biol. 53:275-297.

Feussner, I., Wasternack, C., Kindl, H., and Kuhn, H. 1995. Lipoxygenase-catalysed oxygenation of storage lipids is implicated in lipid mobilization during germination. Proc. Natl. Acad. Sci. U.S.A. 92:11849-11853.

Feussner, I., Kuhn, H., and Wasternack, C. 2001. Lipoxygenase-dependent degradation of storage lipids. Trends Plant Sci. 6:268-273.

Fischer, A. M., Dubbs, W. E., Baker, R. A., Fuller, M. A., Stephenson, L. C., and Grimes, H. D. 1999. Protein dynamics, activity and cellular localization of soybean lipoxygenases indicate distinct functional roles for individual isoforms. Plant J. 19:543-554.

Fobel, M., Lynch, D. V., and Thompson, J. E. 1987. Membrane deterioration in senescing carnation flowers. Coordinated effects of phospholipid degradation and the action of membranous lipoxygenase. Plant Physiol. 85:204-211.

Gardner, H. W. 1991. Recent investigations into the lipoxygenase pathway of plants. Biochim. Biophys. Acta 1084:221-239.

Gardner, C. D., Sherrier, D. J., Kardailsky, I. V., and Brewin, N. J. 1996. Localization of lipoxygenase proteins and mRNA in pea nodules: Identification of lipoxygenase in the lumen of infection threads. Mol. PlantMicrobe Interact. 9:282-289.

Graham, P. H., and Vance, C. P. 2003. Legumes: Importance and constraints to greater use. Plant Physiol. 131:872-877.

Grechkin, A. 1998. Recent developments in biochemistry of the plant lipoxygenase pathway. Prog. Lipid Res. 37:317-352.

Hildebrand, D. F. 1989. Lipoxygenases. Physiol. Plant 76:249-253.

Hildebrand, D. F., Versluys, R. T., and Collins, G. B. 1991. Changes in lipoxygenase isozyme levels during soybean embryo development. Plant Sci. 75:1-8

Hornung, E., Walther, M., Kühn, H., and Feussner, I. 1999. Conversion of cucumber linoleate 13-lipoxygenase to a 9-lipoxygenating species by site-directed mutagenesis. Proc. Natl. Acad. Sci. U.S.A. 96:4192-4197.

Islas-Flores, I., Corrales-Villamar, S., Bearer, E., Raya, J. C., and Villanueva, M. A. 2002. Isolation of lipoxygenase isoforms from Glycine max embryo axes based on apparent cross-reactivity with anti-myosin antibodies. BBA-Gen. Subjects 1571:64-70.

Journet, E. P., Pichon, M., Dedieu, A., Debilly, F., Truchet, G., and Barker, D. G. 1994. Rhizobium meliloti Nod factors elicit cell-specific transcription of the ENOD12 gene in transgenic alfalfa. Plant J. 6:241-249.

Kereszt, A., Dongxue, L., Indrasumunar, A., Cuc, D. T. N., Nontachaiyapoom, S., Kinkema, M., and Gresshoff, P. M. 2007. Agrobacterium rhizogenes-mediated transformation of soybean to study root biology. Nat. Protoc. 2:948-952.

Kinkema, M., Scott, P. T., and Gresshoff, P. M. 2006. Legume nodulation: Successful symbiosis through short- and long-distance signalling. Funct. Plant Biol. 33:707-721.

Kosslak, R. M., and Bohlool, B. B. 1984. Suppression of nodule development of one side of a split-root system of soybeans caused by prior inoculation of the other side. Plant Physiol. 75:125-130.

Kouchi, H., Shimomura, K., Hata, S., Hirota, A., Wu, G. J., Kumagai, H., Tajima, S., Suganuma, N., Suzuki, A., Aoki, T., Hayashi, M., Yokoyama, T., Ohyama, T., Asamizu, E., Kuwata, C., Shibata, D., and Tabata, S. 2004. Large-scale analysis of gene expression profiles during early stages of root nodule formation in a model legume, Lotus japonicus. DNA Res. 11:263-274.

Krusell, L., Madsen, L. H., Sato, S., Aubert, G., Genua, A., Szczyglowski, K., Duc, G., Kaneko, T., Tabata, S., de Bruijn, F., Pajuelo, E., Sandal, N., and Stougaard, J. 2002. Shoot control of root development and nodulation is mediated by a receptor-like kinase. Nature 420:422-426.

Krusell, L., Krause, K., Ott, T., Desbrosses, G., Kramer, U., Sato, S., Nakamura, Y., Tabata, S., James, E. K., Sandal, N., Stougaard, J., Kawaguchi, M., Miyamoto, A., Suganuma, N., and Udvardi, M. K. 2005. The sulfate transporter SST1 is crucial for symbiotic nitrogen fixation in Lotus japonicus root nodules. Plant Cell 17:1625-1636.

Li, C., and Wong, W. W. 2001. Model-based analysis of oligonucleotide arrays: Model validation, design issues and standard error application. Genome Biol. 2:research0032.1-0032.11.

Liavonchanka, A., and Feussner, I. 2006. Lipoxygenases: Occurrence, functions and catalysis. J. Plant Physiol. 163:348-357.

Limpens, E., Franken, C., Smit, P., Willemse, J., Bisseling, T., and Geurts, R. 2003. LysM domain receptor kinases regulating rhizobial Nod factor-induced infection. Science 302:630-633.

Lohar, D. P., Sharopova, N., Endre, G., Penuela, S., Samac, D., Town, C. Silverstein, K. A. T., and VandenBosch, K. A. 2006. Transcript analysis of early nodulation events in Medicago truncatula. Plant Physiol. $140: 221-234$

Loiseau, J., Vu, B. L., Macherel, M. H., and Le Deunff, Y. 2001. Seed lipoxygenases: Occurrence and functions. Seed Sci. Res. 11:199-211.

Madsen, E. B., Madsen, L. H., Radutoiu, S., Olbryt, M., Rakwalska, M., Szczyglowski, K., Sato, S., Kaneko, T., Tabata, S., Sandal, N., and Stougaard, J. 2003. A receptor kinase gene of the LysM type is involved in legume perception of rhizobial signals. Nature 425:637-640.

Mathews, A., Carroll, B. J., and Gresshoff, P. M. 1989. Development of Bradyrhizobium infections in supernodulating and non-nodulating mutants of soybean (Glycine Max [L.] Merrill). Protoplasma 150:4047.

Mohammadi, M., and Karr, A. L. 2003. Induced lipoxygenases in soybean root nodules. Plant Sci. 164:471-479.

Nishimura, R., Hayashi, M., Wu, G. J., Kouchi, H., Imaizumi-Anraku, H., Murakami, Y., Kawasaki, S., Akao, S., Ohmori, M., Nagasawa, M., Harada, K., and Kawaguchi, M. 2002. HAR1 mediates systemic regulation of symbiotic organ development. Nature 420:426-429.

Nontachaiyapoom, S., Scott, P. T., Men, A. E., Kinkema, M., Schenk, P. 
M., and Gresshoff, P. M. 2007. Promoters of orthologous Glycine max and Lotus japonicus nodulation autoregulation genes interchangeably drive phloem-specific expression in transgenic plants. Mol. PlantMicrobe Interact. 20:769-780.

Oka-Kira, E., Tateno, K., Miura, K., Haga, T., Hayashi, M., Harada, K., Sato, S., Tabata, S., Shikazono, N., Tanaka, A., Watanabe, Y., Fukuhara, I., Nagata, T., and Kawaguchi, M. 2005. klavier (klv), A novel hypernodulation mutant of Lotus japonicus affected in vascular tissue organization and floral induction. Plant J. 44:505-515.

Ott, T., van Dongen, J. T., Gunther, C., Krusell, L., Desbrosses, G., Vigeolas, H., Bock, V., Czechowski, T., Geigenberger, P., and Udvardi, M. K. 2005. Symbolic leghemoglobins are crucial for nitrogen fixation in legume root nodules but not for general plant growth and development. Curr. Biol. 15:531-535.

Pankhurst, C. E., and Sprent, J. I. 1975. Surface features of soybean root nodules. Protoplasma 85:85-98.

Peng, Y. L., Shirano, Y., Ohta, H., Hibino, T., Tanaka, K., and Shibata, D. 1994. A novel lipoxygenase from rice. Primary structure and specific expression upon incompatible infection with rice blast fungus. J. Biol. Chem. 269:3755-3761.

Perlick, A. M., Albus, U., Stavridis, T., Fruhling, M., Kuster, H., and Puhler, A. 1996. The Vicia faba lipoxygenase gene VfLOX1 is expressed in the root nodule parenchyma. Mol. Plant-Microbe Interact. 9:860863.

Porta, H., and Rocha-Sosa, M. 2000. A Phaseolus vulgaris lipoxygenase gene expressed in nodules and in Rhizobium tropici inoculated roots. BBA-Gene Struct. Expr. 1517:139-142.

Porta, H., and Rocha-Sosa, M. 2002. Plant lipoxygenases. Physiological and molecular features. Plant Physiol. 130:15-21.

Porta, H., Rueda-Benitez, P., Campos, F., Colmenero-Flores, J. M., Colorado, J. M., Carmona, M. J., Covarrubias, A. A., and Rocha-Sosa M. 1999. Analysis of lipoxygenase mRNA accumulation in the common bean (Phaseolus vulgaris L.) during development and under stress conditions. Plant Cell Physiol. 40:850-858.

Radutoiu, S., Madsen, L. H., Madsen, E. B., Felle, H. H., Umehara, Y., Gronlund, M., Sato, S., Nakamura, Y., Tabata, S., Sandal, N., and Stougaard, J. 2003. Plant recognition of symbiotic bacteria requires two LysM receptor-like kinases. Nature 425:585-592.

Schnabel, E., Journet, E. P., de Carvalho-Niebel, F., Duc, G., and Frugoli, J. 2005. The Medicago truncatula SUNN gene encodes a CLV1-like leucine-rich repeat receptor kinase that regulates nodule number and root length. Plant Mol. Biol. 58:809-822.

Searle, I. R., Men, A. E., Laniya, T. S., Buzas, D. M., Iturbe-Ormaetxe, I., Carroll, B. J., and Gresshoff, P. M. 2003. Long-distance signaling in nodulation directed by a CLAVATA1-like receptor kinase. Science 299:109-112.
Sembdner, G., and Parthier, B. 1993. The biochemistry and the physiological and molecular actions of jasmonates. Annu. Rev. Plant Physiol. Plant Mol. Biol. 44:569-589.

Shibata, D., and Axelrod, B. 1995. Plant lipoxygenases. J. Lipid Mediat. Cell Signal. 12:213-228.

Siedow, J. N. 1991. Plant lipoxygenase-structure and function. Annu. Rev. Plant Physiol. Plant Mol. Biol. 42:145-188.

Spaink, H. P. 2000. Root nodulation and infection factors produced by rhizobial bacteria. Annu. Rev. Microbiol. 54:257-288.

Stacey, G., Libault, M., Brechenmacher, L., Wan, J. R., and May, G. D. 2006. Genetics and functional genomics of legume nodulation. Curr. Opin. Plant Biol. 9:110-121.

Staehelin, C., Müller, J., Mellor, R. B., Wiemken, A., and Boller, T. 1992. Chitinase and peroxidase in effective $\left(\mathrm{fix}^{+}\right)$and ineffective (fix ${ }^{-}$) soybean nodules. Planta 187:295-300.

Steczko, J., Donoho, G. P., Clemens, J. C., Dixon, J. E., and Axelrod, B. 1992. Conserved histidine-residues in soybean lipoxygenase. Functional consequences of their replacement. Biochemistry 31:4053-4057.

Szczyglowski, K., Hamburger, D., Kapranov, P., and deBruijn, F. J. 1997. Construction of a Lotus japonicus late nodulin expressed sequence tag library and identification of novel nodule-specific genes. Plant Physiol. 114:1335-1346

Thomas, A. L., Guerreiro, S. M. C., and Sodek, L. 2005. Aerenchyma formation and recovery from hypoxia of the flooded root system of nodulated soybean. Ann. Bot. 96:1191-1198.

Tranbarger, T. J., Franceschi, V. R., Hildebrand, D. F., and Grimes, H. D. 1991. The soybean 94-kilodalton vegetative storage protein is a lipoxygenase that is localized in paravenous mesophyll cell vacuoles. Plant Cell 3:973-987.

Veronico, P., Giannino, D., Melillo, M. T., Leone, A., Reyes, A., Kennedy, M. W., and Bleve-Zacheo, T. 2006. A novel lipoxygenase in pea roots. Its function in wounding and biotic stress. Plant Physiol. 141:1045-1055.

Vincent, J. M. 1970. A Manual for the Practical Study of the Root-nodule Bacteria. Blackwell Scientific Publications, Oxford.

Wisniewski, J. P., Gardner, C. D., and Brewin, N. J. 1999. Isolation of lipoxygenase cDNA clones from pea nodule mRNA. Plant Mol. Biol. 39:775-783.

Zimmerman, D. C., and Coudron, C. A. 1979. Identification of traumatin, a wound hormone, as 12-oxo-trans-10-dodecenoic acid. Plant Physiol. 63:536-541.

\section{AUTHOR-RECOMMENDED INTERNET RESOURCE}

Dana Farber Cancer Institute and Harvard School of Public Health dChip software website: www.dchip.org 